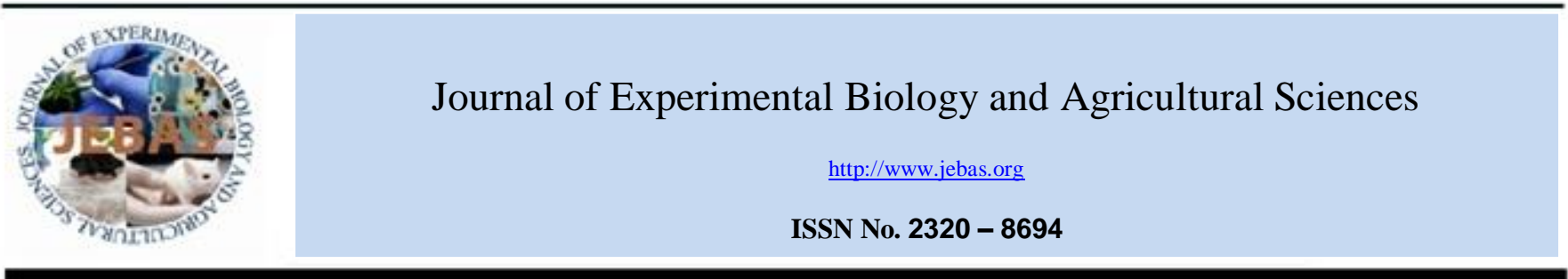

\title{
In vitro CYTOTOXIC EFFECTS OF HYBRID GRAPHENE OXIDE NANOCOMPOSITES (hGONCs) ON CRYOPRESERVED CAPRINE WHARTON'S JELLY DERIVED MESENCHYMAL STEM CELLS (WJ-MSCs)
}

\author{
Sandeep A. Dhenge ${ }^{1 *}$, Nitin E. Gade ${ }^{2}$, Omprakash Mishra $^{2}$, Mangesh M. Vaidya ${ }^{1}$ \\ ${ }^{1}$ Department of Veterinary Physiology, College of Veterinary \& Animal Sciences (MAFSU, Nagpur), Udgir, Dist. Latur (M.S.) India-413 517 \\ ${ }^{2}$ Department of Veterinary Physiology\& Biochemistry, College of Veterinary Science \& Animal Husbandry (CGKV, Durg), Anjora, Durg (C.G.) India-491 001
}

Received - February 11, 2019; Revision - April 03, 2019; Accepted - May 16, 2019

Available Online - June 10, 2019

DOI: http://dx.doi.org/10.18006/2019.7(3).335.342

KEYWORDS
Nanotechnology
Graphene
Cryopreservation
Caprine
Stem cells

\begin{abstract}
In present study, caprine Wharton's jelly derived mesenchymal stem cells (WJ-MSCs) were isolated and characterized by osteogenic and adipogenic differentiation. Total 12 hybrid graphene oxide nanocomposites (hGO NCs) such as $\mathrm{N}_{2}$ doped GO-HA NCs, P doped GO-HA NCs, S doped GO-HA $\mathrm{NCs}, \mathrm{N}_{2}$ doped GO-SiO 2 NCs, $\mathrm{P}$ doped GO-SiO${ }_{2} \mathrm{NCs}$, $\mathrm{S}$ doped GO-SiO${ }_{2} \mathrm{NCs}, \mathrm{N}_{2}$ doped GO-TiO $\mathrm{NCs}_{2}$, $\mathrm{P}$ doped GO-TiO 2 NCs, $\mathrm{S}$ doped GO-TiO $\mathrm{NCs}_{2} \mathrm{~N}_{2}$ doped GO-Au NCs, P doped GO-Au NCs and $\mathrm{S}$ doped GO-Au NCs were incorporated at doses 100, 50, 25, 10 and $0 \mu \mathrm{g} / \mathrm{ml}$ in vitrification solution. Caprine WJ-MSCs were cryopreserved by using open pulled straw (OPS) vitrification method and analysed hGO NCs effect on their post thaw viability and culture characteristics. Caprine WJ-MSCs were exhibited normal fibroblastoid morphology and differentiated in to osteogenic and adipogenic lineages. The significant $(\mathrm{P}<0.01)$ highest and lowest caprine WJ-MSCs post thaw viability (cumulatively) was observed in $\mathrm{P}-\mathrm{GO}-\mathrm{TiO}_{2} \mathrm{NC}$ and $\mathrm{P}-\mathrm{GO}-\mathrm{HA} \mathrm{NC}$ groups, respectively along with all doses (cumulatively) significantly $(\mathrm{P}<0.01)$ decreased post thaw cell viability as compared with control. All hGO NCs were significantly $(\mathrm{P}<0.01)$ decreased caprine WJ-MSCs post thaw viability at doses 100 and $50 \mu \mathrm{g} / \mathrm{ml}$ as compared to 25,10 and $0 \mu \mathrm{g} / \mathrm{ml}$ doses. Post thaw caprine WJ-MSCs were grew in normal pattern with similar fibroblast like morphology on days 14 . In conclusion, all hGO NCs at doses 50 and $100 \mu \mathrm{l} / \mathrm{ml}$ are cytotoxic and $\mathrm{P}-\mathrm{GO}-\mathrm{TiO}_{2} \mathrm{NC}$ is least decrease caprine WJ-MSCs post thaw viability.
\end{abstract}

* Corresponding author

E-mail: drdhenge2009@gmail.com (Sandeep A. Dhenge)

Peer review under responsibility of Journal of Experimental Biology and Agricultural Sciences.

Production and Hosting by Horizon Publisher India [HPI] (http://www.horizonpublisherindia.in/).

All rights reserved.
All the articles published by Journal of Experimental Biology and Agricultural Sciences are licensed under a Creative Commons Attribution-NonCommercial 4.0 International License Based on a work at www.jebas.org.

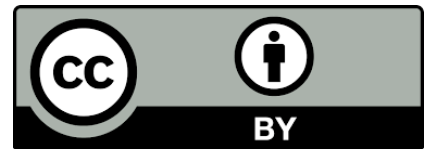




\section{Introduction}

Nanotechnology is the study of materials and structures which are manipulate at nanoscale level and usually, a deliberately engineered material with at least one dimension $1-100 \mathrm{~nm}$ is called as nanomaterial (Hornyak et al., 2008). It is applied in different fields such as chemistry, energy, textile, cosmetics, space research, information technology, biomedicine and agricultural. Recently various types of nanomaterials are widely used in biomedicine for drug discovery (Estelrich et al., 2015) and delivery (Ambwani et al., 2018), bio-imaging (Lobatto et al., 2012), tissue engineering and regenerative medicine (Jayakumar et al., 2011), proteomics (Patil et al., 2015), genomics (Basu et al., 2013), in vitro disease diagnosis (Mamaeva et al., 2018) along with treatment (Kamaly et al., 2016) as well as in stem cell research (Deb et al., 2012). In stem cell research, nanotechnology is applied in stem cell culture (Goto et al., 2007), expansion, differentiation and transplantation (Guo et al., 2017), nano delivery of DNA, RNAi and proteins in stem cells differentiation (Park et al., 2011) as well as in vivo delivery (Nguyen, 2013) and imaging of stem cells (Michalet et al., 2005). Stem cells are specialized progenitor cells residing in nearly all organ tissue and have enormous potency to self-renew and repairs damage cells and differentiate in vitro into their lineage cells. Mesenchymal stem cells (MSCs) are adult stem cells and can be isolated from bone marrow and fetal adnexa tissue and differentiate into osteocytes, adipocytes and chondrocytes (Pittenger et al., 1999), pancreatic cells (Saman et al., 2014), hepatocytes (Borhani et al., 2015) and were used to treat numerous regenerative diseases (Sangeetha et al., 2017). Fetal adnexa derived MSCs can be isolated easily and Umbilical cord Wharton's jelly derived MSCs (WJ-MSCs) expand rapidly and differentiate into osteocytes, adipocytes and chondrocytes (Somal et al., 2016; Somal et al., 2017). Carbon-based nanomaterials (CBNs) are considered as excellent nanomaterials in tissue engineering (Oprych et al., 2016) and other biological applications (Yang et al., 2007) due to their relative biocompatibility. Graphene (GN) is an atom thick pure carbon monolayer arranged in two-dimensional honeycomb structure (Allen et al., 2010) and its derivatives as graphene oxide (GO) and reduced graphene oxide (rGO) were applied in biotechnology (Kim et al., 2011). However, dose and exposure time depended cytotoxicity of hybrid graphene nanomaterials i.e. graphene-based nanomaterials (GBNs) was reported in A549 lung epithelial cells (Wadhwa et al., 2011), 264.7 RAW macrophage (Szczypta et al., 2012; Figarol et al., 2015) and caprine WJ-MSCs (Dar et al., 2015; Gade et al., 2015). In spite this, certain GBNs were showed biocompatibility in human osteoblast (Baradaran et al., 2014), mouse osteoblastic MC3T3-E1 cells (Nishida et al., 2014), caprine BM-MSCs (Elkhenany et al., 2015) and murine MSCs (Kim et al., 2018) in dose dependent manner. In addition,
GO hybridization or doping with organic or inorganic nanomaterials or nanoparticles exploit their unique properties (Wang et al., 2012) and biocompatibility (Nishida et al., 2014) in stem cells. In vitro maintenance of stem cells is difficult task as it changes in its genotype and phenotype, lead to senescence and transformation as well as contaminated in incubator. Hence, stem cells cryopreservation technique can provide potential and regular stem cells source, save time and also culture materials. Stem cells were cryopreserved using vitrification by opened pulled straw (OPS) method (Bahadori et al., 2009), but post thaw survival rate is so variable, however, nanoparticles incorporation in cryoprotectant solution might improve efficiency of vitrification solution by changing its chemical properties (Li et al., 2016; Xu et al., 2016). However, best of our knowledge, invitro efficacy of hybrid graphene oxide (hGO) as GO doped with nitrogen $\left(\mathrm{N}_{2}\right)$, phosphorus (P) and sulphur (S) and their nanocomposites with hydroxyapatite (HA), Silica ( $\mathrm{Si})$, Titanium oxide $\left(\mathrm{TiO}_{2}\right)$ and gold $\mathrm{Au}$ ) were not studied instem cells. hGO NCs may be useful in stem cell research, regenerative medicine and also stem cells post thaw survivability rate can be increased by their incorporation in vitrification solution. Hence, in vitro efficacy of hGONCs in animal stem cell model is an important and therefore, present study was carried with the objective to study comparative in vitro effect of hGO NC soncaprine WJ-MSCs by studying post thaw cell viability.

\section{Materials and Methods}

Present study was conducted in Department of Veterinary Physiology and Biochemistry, College of Veterinary Science and Animal Husbandry, Anjora, Durg (C.G.)-491 001 India and study protocol approved by Institution Animal Ethical Committee (No. VPB/PhD-1/2017).

\subsection{Isolation of caprine WJ-MSCs}

Gravid caprine uteri (45-60 days) were collected from nearby slaughter house and uteri were transported within $1 \mathrm{hr}$ to Department of Veterinary Physiology and Biochemistry, College of Veterinary Science and Animal Husbandry, Anjora, Durg, Chhattisgarh, India. Uteri were washed thoroughly by sterile saline and aseptically 2-3 cm long umbilical cord was cut and proceeded to isolate WJ-MSCs (Babaei et al., 2008). Caprine WJ-MSCs were cultured in Dulbecco's modified eagles' medium (DMEM) fortified with $15 \%$ Fetal Bovine Serum (FBS) and kept in $\mathrm{CO}_{2}$ incubator at $37^{\circ} \mathrm{C}$ with $5 \% \mathrm{CO}_{2}$. Cells were observed periodically under inverted microscope and culture media was changed every after $4^{\text {th }}$ days and cells were passaged on day 14 and third passaged caprine WJ-MSCs were characterized with Alzarin red and Oil red $\mathrm{O}$ staining (Baghaban et al., 2008) to test their osteogenic and adipogenic differentiation potential, respectively. 


\subsection{Hybrid graphene oxide nanocomposites (hGO NCs)}

Total 12 hGO NCs such as $\mathrm{N}_{2}$ doped GO-HA NCs, P doped GOHA NCs, $\mathrm{S}$ doped GO-HA NCs, $\mathrm{N}_{2}$ doped GO-SiO ${ }_{2} \mathrm{NCs}$, P doped GO-SiO ${ }_{2} \mathrm{NCs}$, $\mathrm{S}$ doped GO-SiO${ }_{2} \mathrm{NCs}, \mathrm{N}_{2}$ doped GO-TiO ${ }_{2} \mathrm{NCs}, \mathrm{P}$ doped $\mathrm{GO}-\mathrm{TiO}_{2} \mathrm{NCs}$, S doped $\mathrm{GO}-\mathrm{TiO}_{2} \mathrm{NCs}, \mathrm{N}_{2}$ doped $\mathrm{GO}-\mathrm{Au}$ NCs, P doped GO-Au NCs and S doped GO-Au NCs were generously supplied by Department of Physics, BHU, Banaras, Uttar Pradesh (India). hGO NCs were sterilized and total 5 treatment groups with different doses $(100 \mu \mathrm{g} / \mathrm{ml}, 50 \mu \mathrm{g} / \mathrm{ml}, 25$ $\mu \mathrm{g} / \mathrm{ml}, 10 \mu \mathrm{g} / \mathrm{ml}$ and $0 \mu \mathrm{g} / \mathrm{ml}$ ) were constituted to study effect of hGO NCs on caprine WJ-MSCs post thaw viability.

\subsection{Cryopreservation of caprine WJ-MSCs}

Third passaged caprine WJ-MCSs were cryopreserved with hGO NCs by using open pulled straw (OPS) vitrification method (Vajta et al., 1997; Vajta et al., 1998) with some modifications. Cells were harvested and cryopreserved by using equilibration [10\% Ethylene Glycol (EG) + $10 \%$ Dimethyl Sulphoxide (DMSO)] and vitrification $(20 \% \mathrm{EG}+20 \% \mathrm{DMSO}+0.5 \mathrm{M} / \mathrm{L}$ sucrose) solutions in DMEM supplied with $20 \%$ FBS. hGO NCs were added in vitrification solution as per designed doses to study cytotoxicity. Caprine WJMSCs transferred in media and suspended in equilibration solution for 5 minute and then vitrification solution mixed for 30 - 40 second. Cells droplets were loaded in sterilized French pulled straws by capillary effect and submerged immediately into liquid nitrogen and stored for 7 days. Cells were thawed and suspended in DMEM with 15\% FBS and cell viability was assessed (Bregoli et al., 2009).

\subsection{Statistical analysis}

The data recorded in present study was analyzed with Full Factorial design and One way - ANOVA (IBM SPSS Statistics 25 software) and values are expressed as mean \pm standard error (S. E.) and $\mathrm{P}<0.01$ and $\mathrm{P}<0.05$ are considered to be statistically significant.

\section{Results}

Caprine WJ-MSCs are plastic adherent and exhibited heterogenous morphology however, mostly fibroblastoid like cells were observed and reached confluent stage on day 14 (Figure 1).
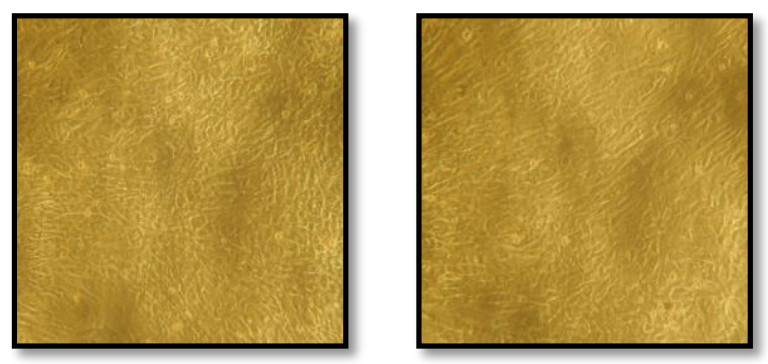

Figure 1 Caprine WJ-MSCs in confluent stage on day 14
The third passage caprine WJ-MSCs were induced with respective differentiation media for 21 days to differentiate into osteocytes and adipocytes and stained positively with Alzarine red (figure 2A) and Oil red O staining(figure 2B), respectively.
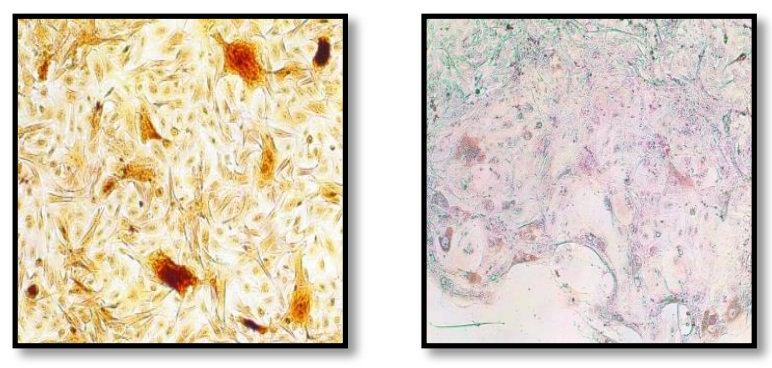

Figure 2 Characterization of WJ-MSCs [A.] Alzarin red staining and [B.] Oil red O staining

Post thaw viability of caprine WJ-MSCs with hGO NCs in vitrification solution was analyzed after 7 days of cryopresrvation. The cumulative significant $(\mathrm{P}<0.01)$ highest and lowest caprine WJ-MSCs post thaw cell viability was observed in $\mathrm{P}-\mathrm{GO}-\mathrm{TiO}_{2}$ $\mathrm{NC}$ and P-GO-HA NC added groups, respectively among all hGO NCs (Table 1). In addition, caprine WJ-MSCs post thaw viability significantly $(\mathrm{P}<0.01)$ decreased in all doses of hGO NCs (cumulatively) as compared with control however, 100 and 50 $\mu \mathrm{g} / \mathrm{ml}$ doses significantly $(\mathrm{P}<0.01)$ decreased post thaw cell viability as compared with 25 and $10 \mu \mathrm{g} / \mathrm{ml}$ (Table 2).

Table 1 Cumulative effect of each hGO NCs on caprine WJMSCs post thaw viability

\begin{tabular}{|ccc|}
\hline Sr. No. & hGO NCs & Post thaw viability \% \\
\hline 1. & $\mathrm{~N}_{2}-\mathrm{GO}-\mathrm{HA} \mathrm{NC}$ & $50.40 \pm 1.74^{\mathrm{abc}}$ \\
\hline 2. & $\mathrm{P}-\mathrm{GO}-\mathrm{HANC}$ & $45.93 \pm 2.29^{\mathrm{a}}$ \\
\hline 3. & $\mathrm{~S}-\mathrm{GO}-\mathrm{HANC}$ & $49.93 \pm 2.40^{\mathrm{abc}}$ \\
\hline 4. & $\mathrm{~N}_{2}-\mathrm{GO}-\mathrm{SiO}_{2} \mathrm{NC}$ & $50.53 \pm 1.63^{\mathrm{abc}}$ \\
\hline 5. & $\mathrm{P}^{\mathrm{abO}}-\mathrm{SiO}_{2} \mathrm{NC}$ & $51.33 \pm 1.69^{\mathrm{bc}}$ \\
\hline 6. & $\mathrm{~S}-\mathrm{GO}-\mathrm{SiO}_{2} \mathrm{NC}$ & $49.53 \pm 1.90^{\mathrm{abc}}$ \\
\hline 7. & $\mathrm{~N}_{2}-\mathrm{GO}-\mathrm{TiO}_{2} \mathrm{NC}$ & $46.60 \pm 1.78^{\mathrm{ab}}$ \\
\hline 8. & $\mathrm{P}-\mathrm{GO}-\mathrm{TiO}_{2} \mathrm{NC}$ & $51.53 \pm 2.02^{\mathrm{c}}$ \\
\hline 9. & $\mathrm{~S}-\mathrm{GO}-\mathrm{TiO}_{2} \mathrm{NC}$ & $46.93 \pm 2.05^{\mathrm{abc}}$ \\
\hline 10. & $\mathrm{~N}_{2}-\mathrm{GO}-\mathrm{Au} \mathrm{NC}^{\mathrm{ab}}$ & $46.53 \pm 2.47^{\mathrm{ab}}$ \\
\hline 11. & $\mathrm{P}-\mathrm{GO}-\mathrm{Au} \mathrm{NC}^{\mathrm{N}}$ & $46.60 \pm 2.50^{\mathrm{ab}}$ \\
\hline 12. & $\mathrm{~S}-\mathrm{GO}-\mathrm{Au} \mathrm{NC}^{\mathrm{abc}}$ & $47.87 \pm 2.59^{\mathrm{abc}}$ \\
\hline
\end{tabular}

Number of replicate $=15$; Mean values bearing superscript in column differed significantly from each other $(\mathrm{P}<0.01)$ 
Table 2 Cumulative effect of each dose of hGO NCs on caprine WJMSCs post thaw viability

\begin{tabular}{|ccc|}
\hline Sr. No. & Dose $(\mu \mathrm{g} / \mathrm{ml})$ & Post thaw viability $\%$ \\
\hline 1. & 100 & $35.42 \pm 0.71^{\mathrm{a}}$ \\
\hline 2. & 50 & $42.36 \pm 0.81^{\mathrm{b}}$ \\
\hline 3. & 25 & $53.94 \pm 0.61^{\mathrm{c}}$ \\
\hline 4. & 10 & $53.69 \pm 0.53^{\mathrm{c}}$ \\
\hline 5. & 0 & $57.81 \pm 0.46^{\mathrm{d}}$ \\
\hline
\end{tabular}

Number of replicate $=36$; Mean values bearing superscript in column differed significantly from each other $(\mathrm{P}<0.01)$
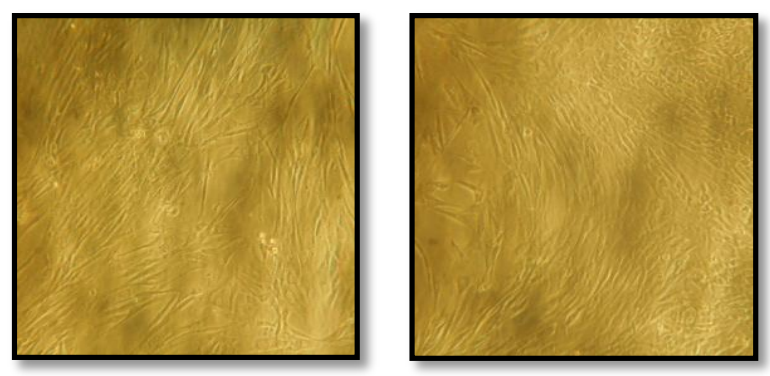

Figure 3 Caprine WJ-MSCs post thaw morphology on day [A.] $12^{\text {th }}$ and $\left[\right.$ B.] $14^{\text {th }}$
However, each hGO NC significantly $(\mathrm{P}<0.01)$ decreased caprine WJ-MSCs post thaw viability in doses 100 and 50 $\mu \mathrm{g} / \mathrm{ml}$ as compared to 25,10 and $0 \mu \mathrm{g} / \mathrm{ml}$ doses which nonsignificantly differed (Table 3 ). Here, it showed that, each hGO NC in doses 25 and $10 \mu \mathrm{g} / \mathrm{ml}$ vitrification solution not caused any significant cytotoxic effect on caprine WJ-MSCs post thaw viability.

Post thaw caprine WJ-MSCs were grew in colonies and observed elongated morphology typical as fibroblast cells and only minute cells were floated in media and detached from surfaces and observed confluent monolayer on days $14^{\text {th }}$ (Figure 3 ).

\section{Discussion}

The aim of the present experiment was to study comparative effect of hGO NCs on caprine WJ-MSCs post thaw viability. Caprine WJ-MSCs were successfully isolated and cultured till third passage and phenotypically characterized by Alzarin red and Oil red $\mathrm{O}$ staining and confirmed their osteocytes and adipocytes differentiation capability, respectively (Figure 2). Caprine WJMSCs are fibroblast like cells which differentiated into osteocytes, adipocytes and chondrocytes (Somal et al., 2016) and cryopreservation did not alter their stemness but, post thaw cell viability was reduced $(<60 \%)$ as like present study in control

Table 3 Effect of hGO NCs on caprine WJ-MSCs post thaw viability $(n=3, P<0.01)$

\begin{tabular}{|c|c|c|c|c|c|c|}
\hline \multirow{2}{*}{ Sr. No. } & \multirow{2}{*}{ hGO NCs } & \multicolumn{5}{|c|}{ Post thaw cell viability $\%$ at different doses } \\
\hline & & 100 & 50 & 25 & 10 & 0 \\
\hline 1. & $\mathrm{~N}_{2}$-GO-HA NC & $37.67 \pm 2.40^{\mathrm{a}}$ & $47.67 \pm 2.03^{\mathrm{b}}$ & $54.33 \pm 3.71^{\mathrm{bc}}$ & $54.67 \pm 1.45^{\mathrm{bc}}$ & $57.67 \pm 2.03^{\mathrm{c}}$ \\
\hline 2. & P-GO-HA NC & $32.33 \pm 2.96^{\mathrm{a}}$ & $38.00 \pm 1.53^{\mathrm{a}}$ & $51.33 \pm 3.38^{\mathrm{b}}$ & $50.67 \pm 3.38^{\mathrm{b}}$ & $57.33 \pm 2.73^{\mathrm{b}}$ \\
\hline 3. & S-GO-HA NC & $34.00 \pm 2.08^{\mathrm{a}}$ & $42.67 \pm 2.03^{\mathrm{b}}$ & $57.00 \pm 1.15^{\mathrm{c}}$ & $55.33 \pm 1.76^{\mathrm{c}}$ & $60.67 \pm 1.45^{\mathrm{c}}$ \\
\hline 4. & $\mathrm{~N}_{2}-\mathrm{GO}-\mathrm{SiO}_{2} \mathrm{NC}$ & $39.67 \pm 4.63^{\mathrm{a}}$ & $47.67 \pm 2.96^{\mathrm{ab}}$ & $52.00 \pm 3.79^{\mathrm{bc}}$ & $54.33 \pm 1.86^{\mathrm{bc}}$ & $59.00 \pm 1.73^{\mathrm{c}}$ \\
\hline 5. & $\mathrm{P}-\mathrm{GO}-\mathrm{SiO}_{2} \mathrm{NC}$ & $40.00 \pm 1.53^{\mathrm{a}}$ & $46.33 \pm 0.88^{\mathrm{b}}$ & $55.67 \pm 2.33^{\mathrm{c}}$ & $56.33 \pm 1.45^{\mathrm{c}}$ & $58.33 \pm 1.76^{\mathrm{c}}$ \\
\hline 6. & $\mathrm{~S}-\mathrm{GO}-\mathrm{SiO}_{2} \mathrm{NC}$ & $36.00 \pm 2.89^{\mathrm{a}}$ & $45.67 \pm 3.76^{\mathrm{b}}$ & $55.67 \pm 2.03^{\mathrm{c}}$ & $54.00 \pm 2.65^{\mathrm{bc}}$ & $56.33 \pm 1.45^{\mathrm{c}}$ \\
\hline 7. & $\mathrm{~N}_{2}-\mathrm{GO}-\mathrm{TiO}_{2} \mathrm{NC}$ & $36.00 \pm 1.73^{\mathrm{a}}$ & $40.67 \pm 1.76^{\mathrm{a}}$ & $50.67 \pm 2.60^{\mathrm{c}}$ & $50.33 \pm 2.67^{\mathrm{c}}$ & $55.33 \pm 2.03^{\mathrm{c}}$ \\
\hline 8. & P-GO-TiO ${ }_{2} \mathrm{NC}$ & $35.67 \pm 2.03^{\mathrm{a}}$ & $48.00 \pm 2.65^{\mathrm{b}}$ & $56.33 \pm 2.40^{\mathrm{c}}$ & $58.67 \pm 2.03^{\mathrm{c}}$ & $59.00 \pm 2.31^{\mathrm{c}}$ \\
\hline 9. & S-GO-TiO ${ }_{2} \mathrm{NC}$ & $35.00 \pm 3.79^{\mathrm{a}}$ & $39.00 \pm 3.46^{\mathrm{a}}$ & $50.67 \pm 1.45^{\mathrm{b}}$ & $52.00 \pm 2.08^{\mathrm{b}}$ & $58.00 \pm 2.65^{\mathrm{b}}$ \\
\hline 10. & $\mathrm{~N}_{2}$-GO-Au NC & $33.33 \pm 2.60^{\mathrm{a}}$ & $38.33 \pm 1.86^{\mathrm{a}}$ & $54.33 \pm 2.73^{\mathrm{b}}$ & $49.00 \pm 5.03^{\mathrm{b}}$ & $57.67 \pm 2.96^{\mathrm{b}}$ \\
\hline 11. & P-GO-Au NC & $30.00 \pm 3.06^{\mathrm{a}}$ & $39.00 \pm 4.04^{\mathrm{b}}$ & $55.67 \pm 1.45^{\mathrm{c}}$ & $52.67 \pm 0.88^{\mathrm{c}}$ & $55.67 \pm 1.45^{\mathrm{c}}$ \\
\hline 12. & S-GO-Au NC & $35.33 \pm 3.84^{\mathrm{a}}$ & $35.33 \pm 2.33^{\mathrm{a}}$ & $53.67 \pm 2.03^{\mathrm{b}}$ & $56.33 \pm 0.88^{\mathrm{b}}$ & $58.67 \pm 1.20^{\mathrm{b}}$ \\
\hline
\end{tabular}

Mean values bearing superscript in row differed significantly from each other. 
group (Somal et al., 2017). However, hWJ-MSCS post thaw viability not significantly differed and observed $95 \pm 2.3 \%$ survival rate and fibroblast like morphology (Massood et al., 2013) which is also justified in present study that, caprine WJ-MSCs post thaw morphology did not change and cells typically showed their fibroblast like morphology. In addition, post thaw rat BM-MSCs were formed colonies and showed fibroblastic or spindle shaped morphology and post thaw cell viability for vitrification method and OPS vitrification method observed as $81.33 \pm 6.93 \%$ and 80.83 $\pm 6.4 \%$, respectively (Bahadori et al., 2009). GBNs such as graphene quantum dots (Dar et al., 2015), GO- $\mathrm{Fe}_{2} \mathrm{O}_{3} \mathrm{NCs}$ (Gade et al., 2015) and $\mathrm{N}_{2}$-GO-HA NCs (Dhenge et al., 2018) were exhibited dose $(10,25,50$ and $100 \mu \mathrm{g} / \mathrm{ml})$ dependent cytotoxicity in caprine WJ-MSCs. However, nanoparticles incorporation in cryoprotectant solutions can improve potency of vitrification solution ( $\mathrm{Li}$ et al., 2016) by changing its chemical properties (Xu et al., 2016) and this is justified in present study, as all hGO NCs in doses 10 and $25 \mu \mathrm{l} / \mathrm{ml}$ did not significantly $(\mathrm{P}<0.01)$ reduced caprine WJ-MSCs post thaw viability as compared to control (Table 3). But, each hGO NCs in 50 and $100 \mu \mathrm{l} / \mathrm{ml}$ doses were significantly $(\mathrm{P}<0.01)$ reduced caprine WJ-MSCs post thaw viability as compared to 0,10 and $25 \mu \mathrm{l} / \mathrm{ml}$ doses. Hence, in present study it was confirmed that, each hGO NC in doses 10 and $25 \mu \mathrm{l} / \mathrm{ml}$ in vitrification solution did not cause any cytotoxicity in caprine WJ-MSCs during cryopreservation. Here, GO in each hGO NC reduced its cytotoxicity slightly which is in agreement with earlier findings as significantly $(\mathrm{P}<0.01)$ increased human osteoblast viability and alkaline phosphatase activity (ALP) that cultured on HA-GN NCs powder deposited on Ti substrates (Liu et al., 2014). But, high GO concentration (0.5 wt. \%) in film suppressed cell spreading and significantly inhibited both proliferation and ALP activity of MC3T3-E1 cells (Nishida et al., 2014). However, caprine BM-MSCs cultured on GO coated tissue culture plates exhibited fibroblast like typical MSCs morphology, grew in clusters (200-250), >95\% viability with $24 \mathrm{hrs}$ population doubling time and observed similar cellular proliferation in plane as well as GO coated tissue culture plates (Elkhenany et al., 2015) which might be justified in present study as GO absolutely enhanced biocompatibility of each hGO NC in 10 and $25 \mu \mathrm{g} / \mathrm{ml}$ doses by showing similar caprine WJ-MSCs post thaw viability (Table 3). However, cumulatively, significant $(\mathrm{P}<0.01)$ lowest and highest caprine $\mathrm{WJ}-\mathrm{MSCs}$ post thaw viability was observed in $\mathrm{P}$ GO-HA NC and P-GO-TiO ${ }_{2} \mathrm{NC}$ incorporated groups, respectively and this might be due to HA (Baradaran et al.,2014) and $\mathrm{TiO}_{2}$ nanoparticles (Salla et al.,2013) which significantly decreased and increased human osteoblast cell viability and MSCs proliferation, respectively than control. Hybridization of GN and GO with biomineral like HA increased mouse osteoblast (MC3T3-E1) cell viability (Kim et al., 2011) and also Au-GO entered in cytoplasm and increased enhanced Raman signals in HeLa cells with increased survivability and proliferation (Liu et al., 2012). In addition, in support to present study, similarly GO and GO-SiO ${ }_{2}$ nanoparticles significantly increased human neuronal stem cells (hNSCs) viability with highest expression of neuronal (TuJ1, MAP2 and Synapsin) and axonal (GAP43) markers (Solanki et al., 2013). Similarly, GO filler promotes proliferation in L929 and MG63 cell lines but concentration of GO coatings determined in vitro biocompatibility of Ti and HA nano sheets (Li et al., 2014). However, core shell fluorescently labelled 15,60 and $200 \mathrm{~nm}$ size $\mathrm{SiO}_{2}$ nanoparticles exhibited biocompatibility at doses 10, 20, 30, 40 and $50 \mu \mathrm{g} / \mathrm{ml}$ in THP-1 derived macrophages, A549 epithelial cells, HaCaT keratinocytes and NRK-52E kidney cells (Hsiao et al., 2014). In addition, $\sim 50 \mathrm{~nm}, \sim 200 \mathrm{~nm}$ and $\sim 400 \mathrm{~nm}$ size coreshell fluorescent $\mathrm{SiO}_{2}$ nanoparticlesdid not decreased human MSCs viability at concentration 10, 50, 100 and $250 \mu \mathrm{g} / \mathrm{ml}$ (Yang et al., 2017). Also, $\mathrm{TiO}_{2}, \mathrm{SiO}_{2}$ and multi-walled carbon nanotubes (MWCNTs) were exhibited cytotoxicity in 3T3 fibroblast, RAW 264.7 macrophage and human bronchiolar epithelial cells (hT) in 100 and $1000 \mu \mathrm{g} / \mathrm{ml}$ and $\mathrm{SiO}_{2}$ exhibited highest cytotoxicity in RAW cells (Sohaebuddin et al., 2010). These findings are not in agreement with the results of present study where $\mathrm{N}_{2}, \mathrm{P}$ and $\mathrm{S}$ doped hybrid GOs with $\mathrm{SiO}_{2}$ and $\mathrm{TiO}_{2}$ nanoparticles significantly $(\mathrm{P}<0.01)$ decreased caprine WJ-MSCs post thaw viability in 50 and $100 \mu \mathrm{g} / \mathrm{ml}$ doses (Table 3 ) and this difference in cell viability might be due to difference in vitro cell models. However, $\mathrm{SiO}_{2}$ coated HA triphasic (Ca-66.36\%, P-25.33\% and Si-8.29\%) biocomposite $\left(\mathrm{HA}-\mathrm{SiO}_{2}\right)$ scaffolds $(0.3 \times 0.2 \times 0.1 \mathrm{~cm}$ dimension $)$ were showed biocompatibility in rabbit BM-MSCs (Ravindran et al.,2016) which is as supportive to present study findings in doses 10 and $25 \mu \mathrm{g} / \mathrm{ml}$.

\section{Conclusion}

The present study concluded as, caprine WJ-MSCs are fibroblast like cells and differentiate into osteocytes and adipocytes. Post thaw caprine WJ-MSCs viability is decrease by hGO NCs at higher doses (100 and $50 \mu \mathrm{l} / \mathrm{ml}$ ) and amongst all hGO NCs, PGO- $\mathrm{TiO}_{2} \mathrm{NC}$ is least cytotoxic and it can be use at lower doses (25 and $10 \mu \mathrm{l} / \mathrm{ml}$ )in stem cell research.

\section{Acknowledgement}

All the authors are thankful to The Dean, College of Veterinary Science \& A.H., Anjora, Dist. Durg for providing fund and laboratory facilities to conduct present study.

\section{Conflicts of interest}

None declared.

\section{References}

Allen MJ, Tung VC, Kaner RB (2010) Honeycomb carbon: A review of graphene. Chemical Reviews110:132-145. 
Ambwani S, Tandon R, Ambwani TK, Malik YS (2018) Current knowledge on nanodelivery systems and their beneficial applications in enhancing the efficacy of herbal drugs. Journal of Experimental Biology and Agricultural Sciences 6:87-107.

Babaei H, Moshrefi M, Golchin M, Mematollahi-Mahani SN (2008) Assess the pluripotency of caprine umbilical cord Wharton's jelly mesenchymal cells by RT-PCR analysis of early transcription factor nanog. Iranian Journal of Veterinary Surgery 3:57-65.

Baghaban EM, Nazarian H, Taghiyar L (2008) Mesenchymal stem cell isolation from the removed medium of rat bone marrow primary culture and their differentiation skeletal cell lineages. Yakhteh Medical Journal10:65-72.

Bahadori MH, Bahram S, Ebrahim M, Babaei P, Malek MA, Moghaddam MAJ (2009) Cryopreservation of rat bone marrow derived mesenchymal stem cells by two conventional and open pulled straw vitrification methods. Yakhteh Medical Journal11:317-326.

Baradaran S, Moghaddam E, Basirun WJ, Mehrali M, Sookhakian M, Hamdi M, Nakhaei Moghaddam MR, Alias Y (2014) Mechanical properties and biomedical applications of a nanotube hydroxyapatite reduced graphene oxide composite. Carbon69:32-45.

Basu S, Chatterjee S, Bandyopadhyay A, Sarkar K (2013) Potential application of superparamagnetic nanoparticles for extraction of bacterial genomic DNA from contaminated food and environmental samples. Journal of the Science of Food and Agriculture 93:788-793.

Borhani HM, Talaei KT, Ayatollahi M, Vojdani Z (2015) Wharton's jelly derived mesenchymal stem cells can differentiate into hepatocytes like cells by hepg2 cell line extract. Iranian Journal of Medical Sciences 40:143-151.

Bregoli L, Chiarini F, Gambarelli A, Sighinolfi G, Gatti AM, Santi P, Martelli AM, Cocco L (2009) Toxicity of antimony trioxide nanoparticles on human hematopoietic progenitor cells and comparison to cell lines. Toxicology 262:121-129.

Dar RM, Gade NE, Mishra OP, Khan JR, Vinod K, Patiyal A (2015) In vitro cytotoxicity assessment of graphene quantum dots in caprine Wharton's jelly derived mesenchymal stem cells. Journal of Cell Tissue Research 15:4703-4710.

Deb KD, Griffith M, Muinck ED, Rafat M (2012) Nanotechnology in stem cells research: advances and applications. Frontiers in Bioscience1:1747-1760.

Dhenge SA, Gade NE, Mishra OP, Rawat N, Singh V, Srivastava A (2018) In vitro Cytotoxicity Analysis of Nitrogen Doped Graphene Oxide Hydroxyapatite Nanocomposite $\left(\mathrm{N}_{2}-\mathrm{GO}-\mathrm{HA}\right.$
NC) in Caprine Wharton'sJelly Derived Mesenchymal Stem Cells (WJ-MSCs) and Blood Cells. International Journal of Agriculture Sciences 10:6387-6391.

Elkhenany H, Lisa A, Andersen L, Shawn B, Mark C, Nancy N, Enkeleda D, Oshin D Alexandru S, Biris DA, Dhar M (2015) Graphene support in vitro proliferation and osteogenic differentiation of goat adult mesenchymal stem cells: Potential for bone tissue engineering. Journal of Applied Toxicology 35:367-374.

Estelrich J, Escribano E, Queralt J, Busquets MA (2015) Iron oxide nanoparticles for magnetically guided and magnetically responsive drug delivery. International Journal of Molecular Sciences 16:8070-8101.

Figarol A, Jeremie P, Delphine B, Valerie F, Celine A, Jean M T, Jean PL, Michele C, Didier BA, Philippe G (2015) In vitro toxicity of carbon nanotubes, nanographite and carbon black, similar impacts of acid functionalization. Toxicology In Vitro 30:476-485.

Gade NE, Dar RM, Mishra OP, Khan JR, Vinod K, Patyal A (2015) Evaluation of dose dependent cytotoxic effects of graphene oxide-iron oxide nanocomposite on caprine Wharton's jelly derived mesenchymal stem cells. Journal of Animal Research 5:415-421.

Goto M, Tsukahara T, Sato K, Konno T, Ishihara K, Sato K, Kitamori T (2007)Nanometer-scale Patterned Surfaces for Control of Cell Adhesion. Analytical Science 23:245-247.

Guo W, Qiu J, Liu J, Liu H (2017) Graphene microfiber as a scaffold for regulation of neural stem cells differentiation. Scientific Reports 7:5678.

Hornyak GL, Moore JJ, Tibbals HF, Dutta J (2008) Textbook of Fundamentals of Nanotechnology. Taylor \& Francis Group. CRC Press, Boca Raton, New York.

Hsiao I, Gramatke AM, Joksimovic R, Sokolowski M, Gradzielski $M$ (2014) Size and cell type dependent uptake of silica nanoparticles. Journal of Nanomedicine Nanotechnology 5:248.

Jayakumar R, Ramachandran R, Divyarani VV, Chennazhi KP, Tamura H, Nair SV (2011) Fabrication of chitin-chitosan / nano $\mathrm{TiO}_{2}$ composite scaffolds for tissue engineering applications. International Journal of Biological Macromolecules 48:336344.

Kamaly N, John CH, Dennis AA, Omid CF (2016) Nanomedicines for renal disease: Current status and future application. Nature Review: Nephrology12:738-753.

Kim J, Kim HD, Park J, Lee ES, Kim E, Lee SS, Yang JK, Lee YK, Hwang NS (2018) Enhanced osteogenic commitment of murine mesenchymal stem cells on graphene oxide substrate. Biomaterial Research 22:1. 
Kim S, SookH K, Lim SY, Kim J H, Park CB (2011) Graphene biomineral hybrid materials. Advanced Materials 23:2009-2017.

Li M, Liu Q, Jia Z, Xu X, Cheng Y, Zheng Y, Xi T, Wei S (2014) Graphene oxide / hydroxyapatite composite coatings fabricated by electrophoretic nanotechnology for biological applications. Carbon 67:185-197.

Li W, Zhou Z, Liu B, Dai J, Song P, Teng Y (2016) Effect of nanoparticles on the survival and development of vitrified porcine GV oocytes. Cryo Letters 37:401-405.

Liu Q, Wei L, Wang J, Peng F, Luo D, Cui R, Niu Y, Qin X, Liu Y, Sun H, Yang J,Li Y(2012) Cell imaging by graphene oxide based on surface enhanced Raman scattering. Nanoscale 4:7084-7089.

Liu Y, Dang Z, Wang Y, Huang J, Li H (2014) Hydroxyapatite / graphene nanosheet composite coatings deposited by vacuum cold spraying for biomedical applications: Inherited nanostructures and enhanced properties. Carbon 67:250-259.

Lobatto ME, Calcagno C, Metselaar JM, Storm G, Stroes ES, Fayad ZA, Mulder WJ (2012) Imaging the efficacy of antiinflammatory liposomes in a rabbit model of atherosclerosis by non invasive imaging. Methods in Enzymology 508:211-228.

Mamaeva SN, Maksimov GV, Neustroev EP, Munkhalova YA, Antonov SR, Pavlov AN (2018) Use of nanocomposite material based on graphene oxide and silver nanoparticles in research of blood erythrocytes in various diseases. $\quad 2^{\text {nd }}$ International Symposium on Physics, Engineering and Technology for Biomedicine, KnE Energy and Physics, Pp. 212-222.

Massood E, Maryam K, Parvin S, Mojgan M, Noureddin N M(2013) Vitrification of human umbilical cord Wharton's jelly derived mesenchymal stem cells. Cryo Letters 34:471-480.

Michalet X, Pinaud FF, Bentolila LA, Tsay JM, Doose S, Li JJ, Sundaresan G, Wu AM, Gambhir SS, Weiss S (2005) Quantum dots for live cells, in vivo imaging and diagnostics. Science 307:538-544.

Nguyen KT (2013) Mesenchymal stem cells as targeted vehicles to deliver drug loaded nanoparticles for cancer therapy. Journal of Nanomedicine Nanotechnology 4:e128.

Nishida E, Miyaji H, Takita H, Kanayama I, Tsuji M, AkasakaT, Sugaya T, Sakagami R, Kawanami M (2014) Graphene oxide coating facilitates the bioactivity of scaffold material for tissue engineering. Japanese Journal of AppliedPhysics53:06JD04.

Oprych KM, Whitby RLD, Mikhalovsky SV, Tomlins P, Adu J (2016) Repairing peripheral nerves: Is there a role for carbon nanotubes? Advanced Healthcare Materials 5:1253-1271.
Park JS, Yang HN, Woo DG, Jeon SY, Park KH (2011) The promotion of condrogenesis, osteogenesis and adipogenesis of human mesenchymal stem cells by multiple growth factors incorporated in nanosphere coated microsphere. Biomaterials 32:28-38.

Patil US, Osorno L, Ellender A, Grimm C, Tarr MA (2015) Cleavable ester linked magnetic nanoparticles for labeling of solvent exposed primary amine groups of peptides / proteins. Analytical Biochemistry 484:18-20.

Pittenger MF, Mackay AM, Beck SC, Jaiswal RK, Douglas R, Mosca JD, Moorman MA, Simonetti DW, Craig S, Marshak DR (1999) Multilineage potential of adult human mesenchymal stem cells. Science 284:143-147.

Ravindran NA, Maiti SK, Palakkara S, Kritaniya D, Mahan T, Naveen K (2016) In vitro osteoinduction potential of a novel silica coated hydroxyapatite bioscaffold seeded with rabbit mesenchymal stem cell. Journal of Stem Cell Research and Therapeutics 1:00009.

Salla K, Mahonen AJ, Lappalainen R, Kroger H, Lammi MJ, Qu $\mathrm{C}$ (2013) $\mathrm{TiO}_{2}$ coating promotes human mesenchymal stem cell proliferation without the loss of their capacity for chondrogenic differentiation. Biofabrication 5:025009.

Saman G, Afsoon G, Peyman G, Nasibeh D, Mohadese HB (2014) Application of nanoscaffolds in mesenchymal stem cell based therapy. Advances in Regenerative Medicine 369498.

Sangeetha P, Maiti K, Singh K, Gopinathan A, Singh KP, Mohan D, Ninu AR, Kumar N (2017) Evaluation of bio-engineered corneal scaffold for the repair of corneal defect in rabbit model. Indian Journal of Animal Sciences 87:1332-1339.

Sohaebuddin SK, Thevenot PT, Baker D, Eaton JW, Tang L(2010) Nanomaterial cytotoxicity is composition, size and cell type dependent. Particleand Fiber Toxicology7:22.

Solanki A, Chueng STD, Yin PT, Kappera R, Chhowalla M, Lee KB (2013)Axonal alignment and enhanced neuronal differentiation of neural stem cells on graphene nanoparticle hybrid structures. Advanced Materials 25:5477-5482.

Somal A, Bhat I A, Indu B, Pandey S, Panda BSK, Thakur N, Sarkar M, Chandra V, Saikumar G, Sharma GT (2016) A comparative study of growth kinetics, in vitro differentiation potential and molecular characterization of fetal adnexa derived caprine Mesenchymal Stem Cells. PLoS ONE 11:1-17.

Somal A, Bhat IA, Indu B, Singh AP, Panda BSK, Desingu PA, Pandey S, Bharti MK, Pal A, Saikumar G, Chandra V, Sharma G (2017) Impact of cryopreservation on caprine fetal adnexa derived stem cells and its evaluation for growth kinetics, phenotypic 


\section{In Vitro Cytotoxic Effects Of Hybrid Graphene Oxide Nanocomposites (Hgoncs) On Cryopreserved Caprine Wharton's Jelly Derived Mesenchymal Stem Cells (Wj-Mscs) 342}

characterization and wound healing potential in xenogenic rat model. Journal of Cellular Physiology 232:2186-2200.

Szczypta AF, Menaszek E, Syeda TM, Mishra A, Alavijeh M, Adu J, Blazewicz S (2012) Effect of MWCNT surface and chemical modification on in vitro cellular response. Journal of Nanoparticle Research14:1181.

Vajta G, Booth PJ, Holm P, Greve T, Callesen H (1997) Successful vitrification of early stage bovine in vitro produced embryos with the open pulled straw (OPS) method. Cryo Letters 18:191-195.

Vajta G, Holm P, Kuwayama M, Booth PJ, Jocobsen H, Greve T, Challesen H (1998) Open pulled straw (OPS) vitrification: A new way to reduce cryo injuries of bovine embryos and oocytes. Molecular Reproduction and Development 51:53-58.

Wadhwa S, Rea C, Hare P O, Mathur A, Roy SS, Dunlop PS, Byrne JA, Burke G, Meenan B, McLaughlin JA (2011)
Comparative in vitro cytotoxicity study of carbon nanotubes and titanium nanostructures on human lung epithelial cells. Journal of Hazardous Materials 191:56-61.

Wang H, Maiyalagan T, Wang X (2012) Review on recent progress in nitrogen doped graphene: Synthesis, characterization and its potential applications. ACS Catalysis 2:781-794.

Xu H, Hao B, Liu L, Tang L, Liu L (2016)Calorimetric studies on thermal properties of nano-cryoprotectant solutions during vitrification.CryoLetters 37:406-410.

Yang W, Thordarson P, Gooding JJ, Ringer SP, Braet F (2007) Carbon nanotubes for biological and biomedical applications. Nanotechnology 18:412001.

Yang X, Li Y, Liu X, Huang Q, He W, Zhang R, Feng Q, Benayahu D (2017) The stimulatory effect of silica nanoparticles on osteogenic differentiation of human mesenchymal stem cells. Biomedical Materials 12:015001. 